\title{
Filling and unfilling carbon capsules with transition metal oxide nanoparticles for Li-ion hybrid supercapacitors: towards hundred grade energy density
}

\author{
Cuihua $\mathrm{An}^{1,2}$, Xizheng Liu ${ }^{1}$, Zhen Gao ${ }^{1}$ and Yi Ding ${ }^{1 *}$
}

\begin{abstract}
Li-ion hybrid supercapacitors (Li-HECs) facilitate effective combination of the advantages of supercapacitors and Li-ion batteries (LIBs). However, challenges remain in designing and preparing suitable anode and cathode materials, which often require tedious and expensive procedures. Herein, we demonstrated that hollow $\mathrm{N}$-doped carbon capsules (HNC) with and without a $\mathrm{Fe}_{3} \mathrm{O}_{4}$ nanoparticle core can respectively function as the anode and the cathode in very-high-performance Li-HECs. The $\mathrm{Fe}_{3} \mathrm{O}_{4} @ \mathrm{NC}$ anode exhibited a high reversible specific capacity exceeding $1530 \mathrm{~mA}$ $\mathrm{h} \mathrm{g}^{-1}$ at $100 \mathrm{~mA} \mathrm{~g}^{-1}$ and excellent rate capability (45\% capacity retention from 0.1 to $5 \mathrm{~A} \mathrm{~g}^{-1}$ ) and cycle stability ( $>97 \%$ retention after 100 cycles). Moreover, high rate performance was achieved in a full-cell using the HNC cathode. By combining the respective structural advantages of the components, the hybrid device with $\mathrm{Fe}_{3} \mathrm{O}_{4} @ \mathrm{NC} / / \mathrm{HNC}$ exhibited a remarkable energy density of $185 \mathrm{~W} \mathrm{~h} \mathrm{~kg}^{-1}$ at a power density of 39 $\mathrm{W} \mathrm{kg}^{-1}$. The hybrid device furnished a battery-inaccessible power density of $28 \mathrm{~kW} \mathrm{~kg}^{-1}$ with rapid charging/discharging

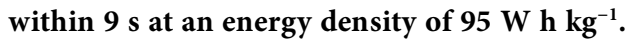

Keywords: carbon capsules, $\mathrm{Fe}_{3} \mathrm{O}_{4}$, high energy density, Li-ion hybrid supercapacitor

\section{INTRODUCTION}

With the increasing demand for portable electronic devices, researchers have focused on developing low-cost, environment-friendly, and high-performance energy storage devices [1,2]. Supercapacitors are known to possess high power density with excellent duration; however, they often suffer from low energy density or low energy/power ratio. Li-ion hybrid supercapacitors (Li-HECs), which are expected to combine the respective advantages of supercapacitors and Li-ion batteries (LIBs), have been proposed as an alternative in order to overcome the inherent limitations of supercapacitors [3-6]. Li-HECs comprise a battery-type anode and a capacitor-type cathode in an organic electrolyte containing a $\mathrm{Li}$ salt as a solute. Since the cathode and anode work reversibly in distinct voltage regions, Li-HECs can potentially achieve excellent rate capability, long cycle life, and high energy density [7-9]. Properly coupling the high-power cathode and high-energy anode in the same device is the primary challenge in the construction of high-performance Li-HECs.

Amatucci et al. [3] first reported a hybrid device, in which activated carbon (AC) was used as the cathode and $\mathrm{Li}_{4} \mathrm{Ti}_{5} \mathrm{O}_{12}$ was used as the anode, and achieved an energy density of $20 \mathrm{~W} \mathrm{~h} \mathrm{~kg}{ }^{-1}$, which was nearly three times that of conventional supercapacitors. Since then, insertion-type materials such as $\mathrm{Li}_{4} \mathrm{Ti}_{5} \mathrm{O}_{12}$ [10], $\mathrm{Li}_{3} \mathrm{VO}_{4}$ [11], $\mathrm{MnO}$ [12], $\mathrm{Fe}_{3} \mathrm{O}_{4}$ [13], and Si-based materials [14-16] have been explored as the electrode materials for Li-HECs. It is worth noting that the discharge voltage plateau of the $\mathrm{Li}_{4} \mathrm{Ti}_{5} \mathrm{O}_{12}$-based anode is $\sim 1.5 \mathrm{~V} v s$. $\mathrm{Li} / \mathrm{Li}^{+}$. Therefore, Li-HECs might undergo mere charge-discharge below $3.2 \mathrm{~V}$, resulting in a narrow operation voltage. Taking into account that $E$ and $P$ have a square relationship with the working voltage, enhancing the working voltage is crucial for improving the overall properties of Li-HECs. Metal oxides are perfect candidates for Li-HEC anodes on

\footnotetext{
${ }^{1}$ Tianjin Key Laboratory of Advanced Functional Porous Materials, Institute for New Energy Materials \& Low-Carbon Technologies, School of Materials Science and Engineering, Tianjin University of Technology, Tianjin 300384, China

${ }^{2}$ Key Laboratory of Advanced Energy Materials Chemistry (MOE), College of Chemistry, Nankai University, Tianjin 300071, China

*Corresponding author (email: yding@tjut.edu.cn or yiding9312@126.com)
} 
account of their relatively low voltage plateau $(\sim 0.8 \mathrm{~V})$ and high theoretical capacity. Thus, a low discharge voltage plateau may dramatically improve the operation voltage [17-19]. Among various metal oxides, $\mathrm{Fe}_{3} \mathrm{O}_{4}$ has earned distinction due to its inherent advantages, including being an abundant natural resource with low cost and high theoretical capacity $\left(924 \mathrm{~mA} \mathrm{~h} \mathrm{~g}^{-1}\right)$ [20]. Carbonaceous materials have been extensively explored for the use as capacitor-type cathode, including AC, carbon nanotubes, and more recently, graphene [21-25]. In current approaches, the anode and cathode materials for Li-HECs are often synthesized individually, inevitably involving lengthy preparation, high cost, and capacity and volume mismatch [26-29]. Therefore, new strategies for one-pot synthesis of inherently compatible cathodes and anodes are highly attractive for further development of Li-HECs.

Herein, based on the comprehensive understanding of the respective energy storage mechanisms in the anode and cathode, we describe a facile route for fabricating such an anode/cathode couple $\left(\mathrm{Fe}_{3} \mathrm{O}_{4} @ \mathrm{NC} / / \mathrm{HNC}\right)$ for full-cell Li-HECs. There are two advantages in this materials design strategy. Firstly, the preparation procedures have been greatly simplified; the hollow N-doped carbon (HNC) cathode is obtained by acid-washing the $\mathrm{Fe}_{3} \mathrm{O}_{4} @ \mathrm{NC}$ anode, which is fabricated via a simple hydrothermal approach. Secondly, the capacities and volume expansion accommodation abilities of the cathode and anode naturally match, which can be ascribed to their common origin and thus structural similarity. By combining the respective structural advantages of the anode and cathode, the thus-constructed Li-HECs (Fig. 1) can effectively accommodate the kinetic discrepancy and attain an appealing energy density of $185 \mathrm{~W} \mathrm{~h} \mathrm{~kg}^{-1}$ electrodes, which remains as approximately hundred-energy density $\left(95 \mathrm{~W} \mathrm{~h} \mathrm{~kg}^{-1}\right)$ when the power density reaches $28 \mathrm{~kW} \mathrm{~kg}^{-1}$ at a rapid charging rate.

\section{EXPERIMENTAL SECTION}

\section{Material preparation}

Mesoporous $\mathrm{Fe}_{3} \mathrm{O}_{4} @ \mathrm{NC}$ nanocomposites were synthesized via a hydrothermal method and post-calcination treatment. Typically, $6.6 \mathrm{mmol}$ of $\left(\mathrm{NH}_{4}\right)_{2} \mathrm{Fe}\left(\mathrm{SO}_{4}\right)_{2} \cdot 6 \mathrm{H}_{2} \mathrm{O}$ and 3 mmol of iminodiacetic acid (IDA) were added to $40 \mathrm{~mL}$ deionized water under constant agitation. The mixture was then transferred into a teflon-lined autoclave, which was incrementally heated to $160^{\circ} \mathrm{C}$ and kept for $8 \mathrm{~h}$. The resulting precipitates were harvested by centrifugation and repeatedly washed with water and ethanol, followed by vacuum drying at $60^{\circ} \mathrm{C}$ overnight. The sample was finally sintered at $600^{\circ} \mathrm{C}$ for $2 \mathrm{~h}$ under $\mathrm{Ar}$ atmosphere.

The HNC was synthesized by etching the synthesized $\mathrm{Fe}_{3} \mathrm{O}_{4} @ \mathrm{NC}$ nanocomposite in $1 \mathrm{~mol} \mathrm{~L}^{-1} \mathrm{HCl}$ solution at $80^{\circ} \mathrm{C}$ for $12 \mathrm{~h}$.

\section{Material characterization}

The crystal structure and surface configuration of the samples were characterized by X-ray diffraction (XRD, Rigaku D/Max-2500, Cu Ka radiation), scanning electron microscopy (SEM, FEI Verios 460L), transmission electron microscopy (TEM), high-resolution TEM (HRTEM), and energy-filtered TEM (EFTEM) on a JEOL JEM-2100 TEM. The synthesized materials were also evaluated by X-ray photoelectron spectroscopy (XPS, PHI 5000 Versaprobe, ULVAC PHI) and Raman spectroscopy (RenishawinVia, excitation $514.5 \mathrm{~nm}$ ). The porous nature and specific surface areas of the $\mathrm{Fe}_{3} \mathrm{O}_{4} @ \mathrm{NC}$ and $\mathrm{HNC}$ samples were further analyzed by nitrogen adsorption/desorption measurements (NOVA 2200e, Quantachrome Instruments). The compositions of the sample were quantified by inductively coupled plasma optical emission spectrometry (ICP-OES, ICP-9000).

\section{Fabrication of the half cell}

For fabrication of the $\mathrm{Fe}_{3} \mathrm{O}_{4} @ \mathrm{NC}$ composite electrode, the active material, acetylene black, and poly(vinylidenefluoride) (PVDF) in N-methyl-2-pyrrolidone (NMP) were blended in a ratio of 85:10:5 to form a slurry, and subsequently deposited onto copper foil. After heating at $80^{\circ} \mathrm{C}$ for $12 \mathrm{~h}$ in vacuum, the sheet was punched into 12 mm-diameter electrodes. A slightly different process was used for fabrication of the cathode. The HNC powder was mixed directly with $10 \%$ PVDF in NMP to form a slurry and was subsequently coated onto $\mathrm{Al}$ foil. The electrochemical properties were assessed using CR2032-type coin cells, which were assembled in an argon-filled glove box. Lithium metal acted as the counter and reference electrodes. The electrolyte comprised $\mathrm{LiPF}_{6}\left(1 \mathrm{~mol} \mathrm{~L}^{-1}\right)$ dissolved in a mixture of ethylene carbonate (EC), ethyl methyl carbonate (EMC), and dimethyl carbonate (DMC) in a volume ratio of 1:1:1.

\section{Fabrication and characterization of the hybrid device}

Li-HECs were assembled in coin cells with pre-lithiated $\mathrm{Fe}_{3} \mathrm{O}_{4} @ \mathrm{NC}$ as the anode, $\mathrm{HNC}$ as the cathode, and Celgard 2400 membrane as the separator. The electrolyte was the same as that in the half cells.

Galvanostatic charge-discharge measurements of the half 
cells and Li-HECs were performed by using a LAND battery test instrument (CT2001A). Cyclic voltammetry (CV) and electrochemical impedance spectroscopy (EIS) were conducted by using a Zahner IM6e electrochemical workstation.

\section{RESULTS AND DISCUSSION}

\section{Morphological and structural analysis}

Fig. 1 presents a schematic illustration of the structure of Li-HECs employing the proposed electrode materials. Firstly, an Fe-based complex with nanorod morphology (Fig. S1) was prepared by using IDA as the chelating agent in a hydrothermal approach. After a short annealing procedure, the $\mathrm{Fe}_{3} \mathrm{O}_{4} @ \mathrm{NC}$ composites were synthesized. Upon further acid etching, the HNC materials, which function as the cathode materials, were prepared.

Fig. 2a highlights the overall morphology of the as-synthesized $\mathrm{Fe}_{3} \mathrm{O}_{4} @ \mathrm{NC}$ composites, in which the parent Fe-IDA nanorod morphology was well-preserved without collapse of the structure. From the zoom-in images in Fig. $2 \mathrm{~b}$ and $\mathrm{c}$, the $\mathrm{Fe}_{3} \mathrm{O}_{4} @ \mathrm{NC}$ nanorods comprise an assembly of numerous spherical particles, which is different from the structure of the precursor Fe-IDA nanorods. TEM characterization (Fig. $2 \mathrm{~d}$ and e) further clarifies that the
$\mathrm{Fe}_{3} \mathrm{O}_{4} @ \mathrm{NC}$ nanorods with porous structure are made up of connected nanoscale sub-units. The HRTEM image in Fig. $2 \mathrm{f}$ demonstrates that the $\mathrm{Fe}_{3} \mathrm{O}_{4}$ particles are crystalline and the interplanar crystal spacing of $0.293 \mathrm{~nm}$ can be ascribed to the 220 plane of $\mathrm{Fe}_{3} \mathrm{O}_{4}$. The sub-units possess a core-shell structure with an ultra-small and homogeneous size $(\sim 15 \mathrm{~nm})$, as demonstrated by the EFTEM images (Fig. $2 \mathrm{~g}$ and $\mathrm{h})$. Moreover, the mapping results demonstrate that the three elements $\mathrm{C}, \mathrm{Fe}$, and $\mathrm{O}$, are homogeneously and uniformly distributed throughout the product (Fig. 2i).

The HNC retains the overall rod-like configuration with a diameter of about $200 \mathrm{~nm}$ (Fig. 3). A high percentage of holes were found after etching the $\mathrm{Fe}_{3} \mathrm{O}_{4}$ core (Fig. 3a). The SEM images further indicate the well-retained HNC nanorods (Fig. 3a). Many three dimensional (3D) interconnected mesopores are uniformly distributed to form the integral rod-like structure (Fig. $3 \mathrm{~b}$ ). The diameter of the big pores between the nanoparticles is $\sim 7 \mathrm{~nm}$ (Fig. 3c), which is suitable for promoting the infiltration of the electrolyte molecules. The HRTEM image (Fig. 3d) illustrates that the big pores are linked to small mesopores (about 4 $\mathrm{nm}$ ) and the walls of the small pores are composed of amorphous carbon. The novel nanostructure offers an opportunity to minimize the inner-pore resistance, resulting in improvement of the ion-accessible surface area. As shown in

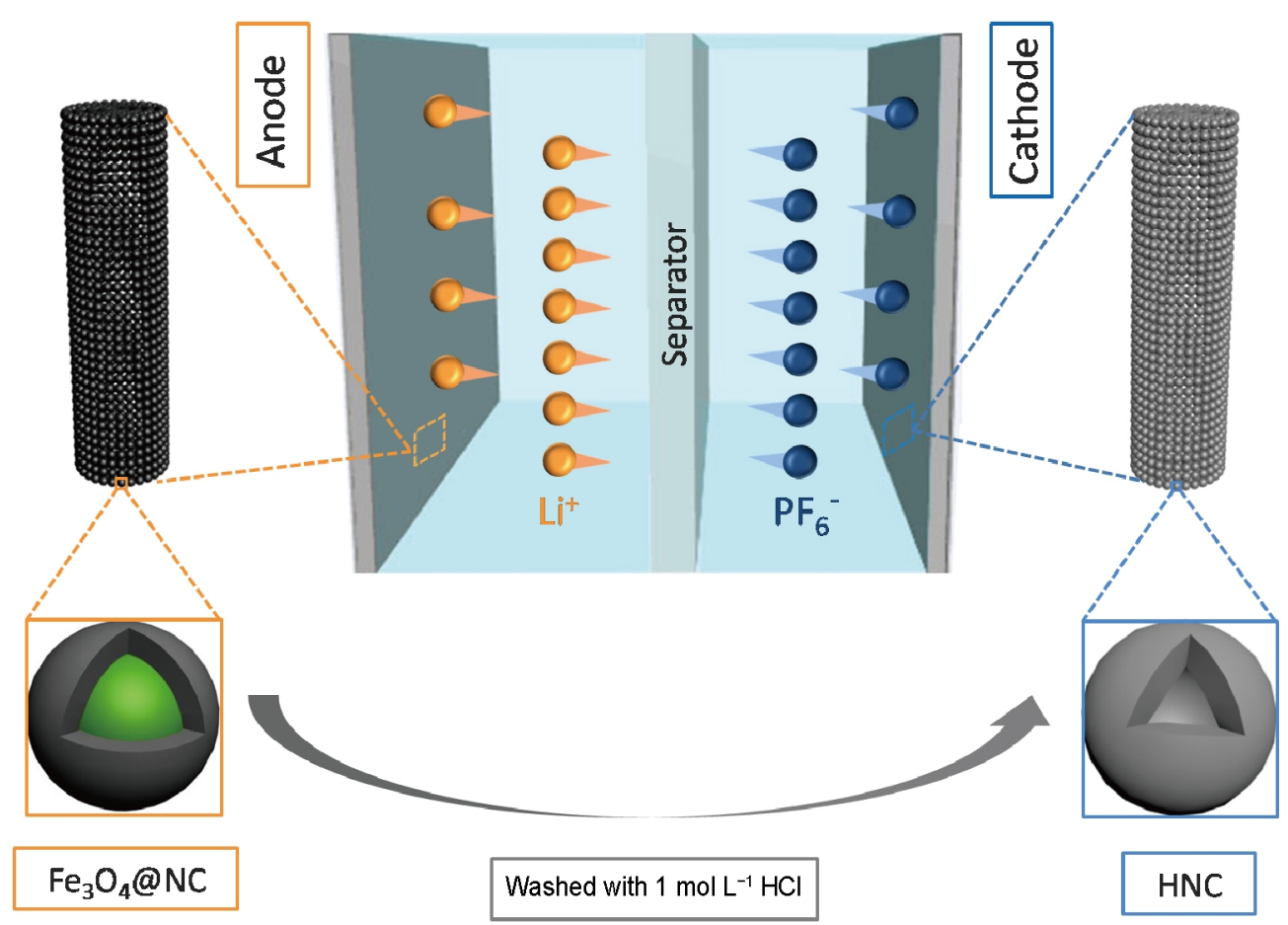

Figure 1 Illustration of the fabricated Li-HECs. The cathode employs HNC materials and the anode utilizes pre-lithiated $\mathrm{Fe}_{3} \mathrm{O}_{4} @ \mathrm{NC}$ hybrids. 

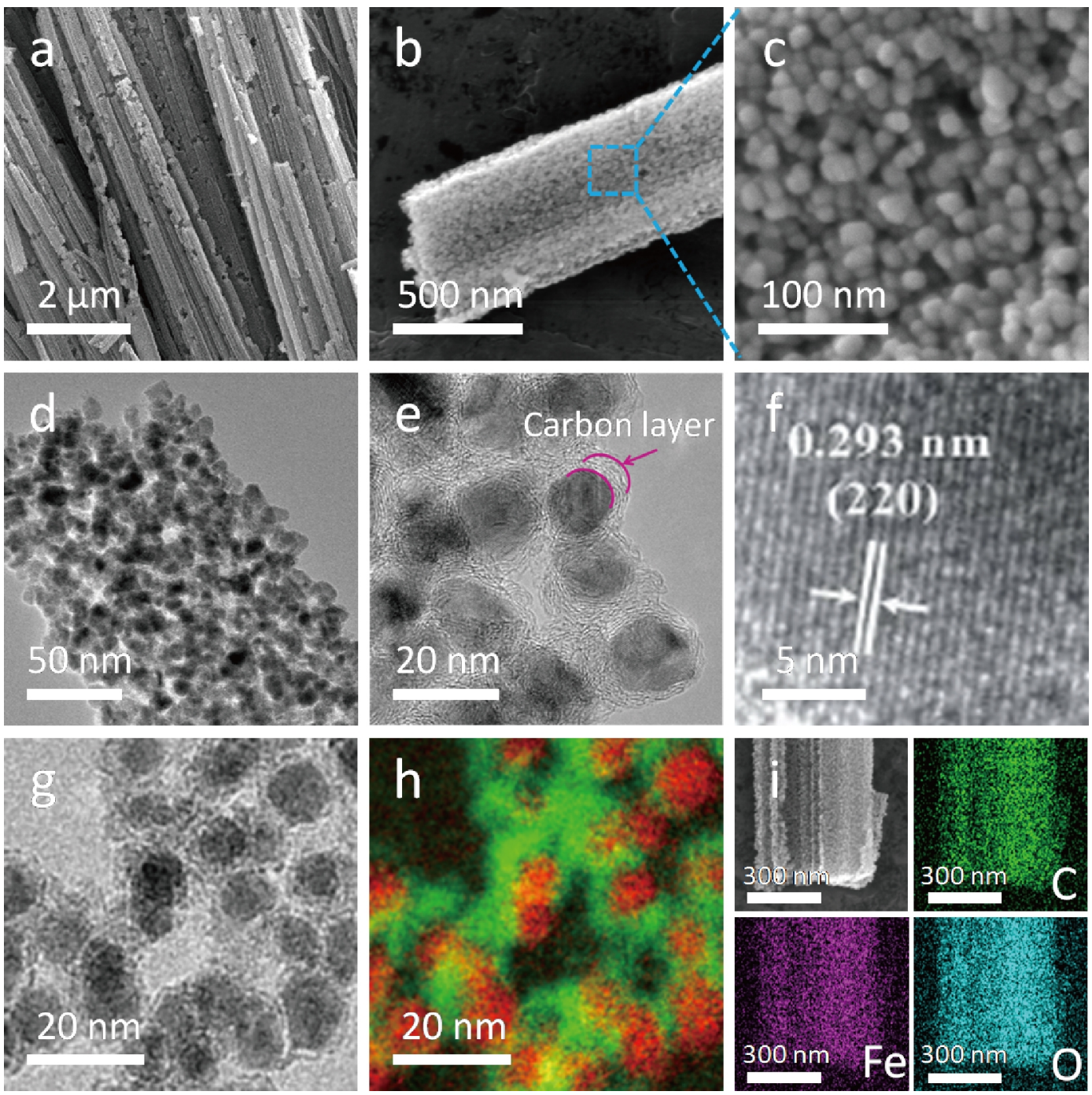

Figure 2 SEM $(\mathrm{a}-\mathrm{c})$, TEM $(\mathrm{d}-\mathrm{f})$, EFTEM $(\mathrm{g}-\mathrm{h})$ images, and the corresponding element mapping (i) of the $\mathrm{Fe}_{3} \mathrm{O}_{4} @ \mathrm{NC}$ electrode material.

Fig. $3 e$ and $\mathrm{f}$, the mapping results demonstrate the homogeneous distribution of $\mathrm{C}$.

As illustrated in Fig. 4a, the XRD profiles of the synthesized $\mathrm{Fe}_{3} \mathrm{O}_{4} @ \mathrm{NC}$ sample correspond to the crystal plane of $\mathrm{Fe}_{3} \mathrm{O}_{4}$ (JCPDS No. 75-1609) and amorphous carbon, as evidenced by the broad peak centered around $25^{\circ}$. No other peaks were detected. Hence, it can be deduced that the Fe-IDA complex is completely converted to $\mathrm{Fe}_{3} \mathrm{O}_{4} @ \mathrm{NC}$ composites. Furthermore, elemental analysis (EA) reveals that the content of carbon and nitrogen are approximately 14.7 and 5.1 wt.\%, respectively. The $\mathrm{Fe}_{3} \mathrm{O}_{4} @ \mathrm{NC}$ Raman spectrum (Fig. 4b) shows the characteristic peaks of $\mathrm{Fe}_{3} \mathrm{O}_{4}$ $\left(302,540\right.$, and $670 \mathrm{~cm}^{-1}$, corresponding to the $\mathrm{E}_{\mathrm{g}}, \mathrm{T}_{2 \mathrm{~g}}$, and $\mathrm{A}_{\mathrm{lg}}$ vibration modes, respectively) [30], and typical peaks of amorphous carbon (D and G bands at about 1345 and $1586 \mathrm{~cm}^{-1}$, corresponding to $\mathrm{sp}^{3}$-type disordered carbon and $\mathrm{sp}^{2}$-type graphitized carbon, respectively). The $I_{\mathrm{D}} / I_{\mathrm{G}}$ value of the $\mathrm{Fe}_{3} \mathrm{O}_{4} @ \mathrm{NC}$ composites is 0.88 , demonstrating a higher content of $\mathrm{sp}^{2}$-type carbon relative to $\mathrm{sp}^{3}$-type, which is beneficial for achieving high electronic conductivity [31].

The HNC could be obtained after leaching the $\mathrm{Fe}_{3} \mathrm{O}_{4}$ nanocrystals. The XRD pattern (Fig. 4a) exhibits a characteristic peak of amorphous carbon at $25^{\circ}$, indicating the complete leaching of $\mathrm{Fe}_{3} \mathrm{O}_{4}$ from the $\mathrm{Fe}_{3} \mathrm{O}_{4} @ \mathrm{NC}$ composite. The Raman spectrum of the HNC is shown in Fig. $4 \mathrm{~b}$. The peaks representing the D- and G-band of amorphous carbon are located at 1337 and $1584 \mathrm{~cm}^{-1}$, respectively. The calculated $I_{\mathrm{D}} / I_{\mathrm{G}}$ value is 0.89 , indicating the high degree of graphitization and the ordered structure of the as-prepared HNC, which is consistent with the HRTEM data (marked by the red circles in Fig. 3d) $[9,13]$. 

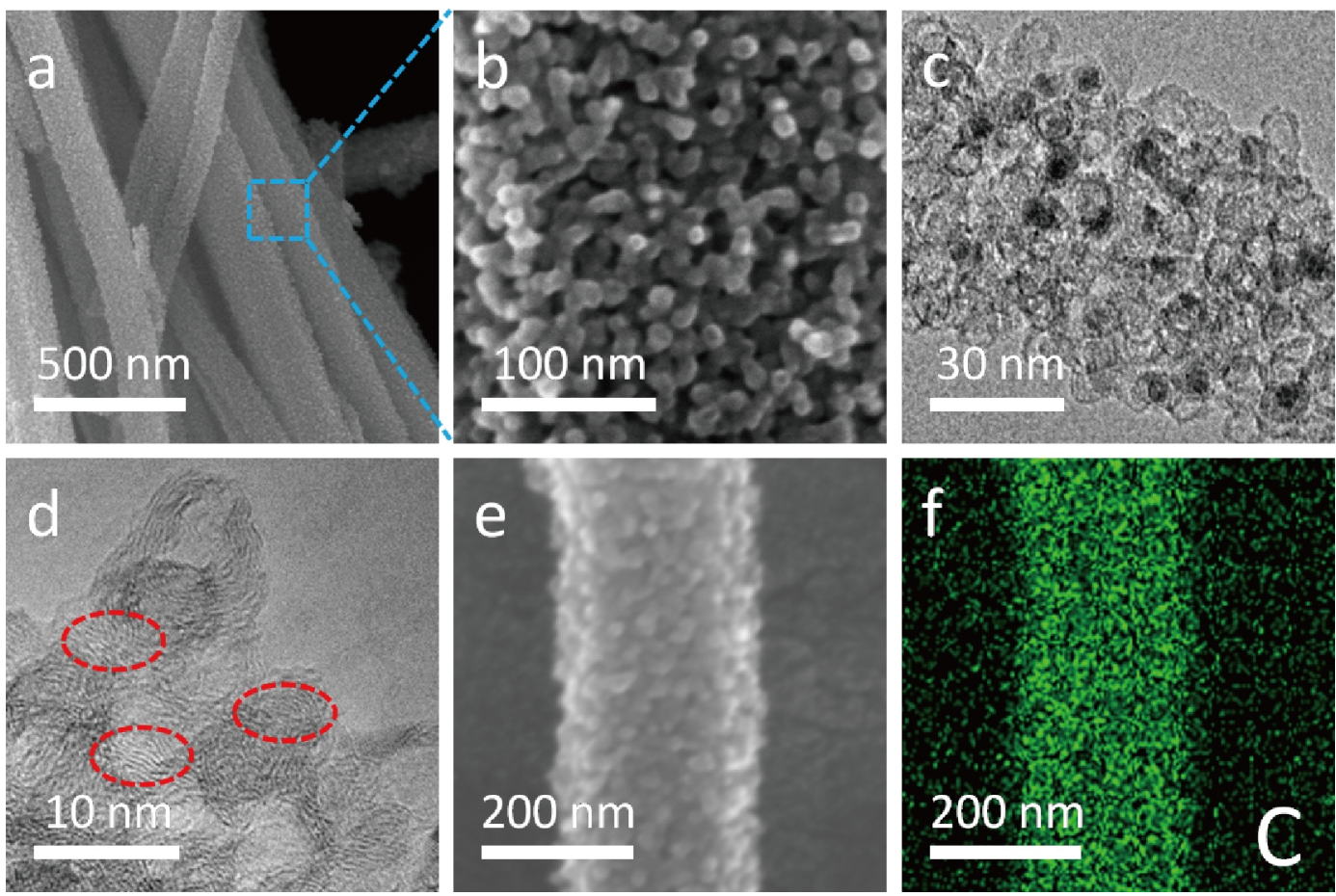

Figure 3 (a, b) SEM, (c, d) TEM images, and the corresponding element mapping (e, f) of the HNC electrode material.
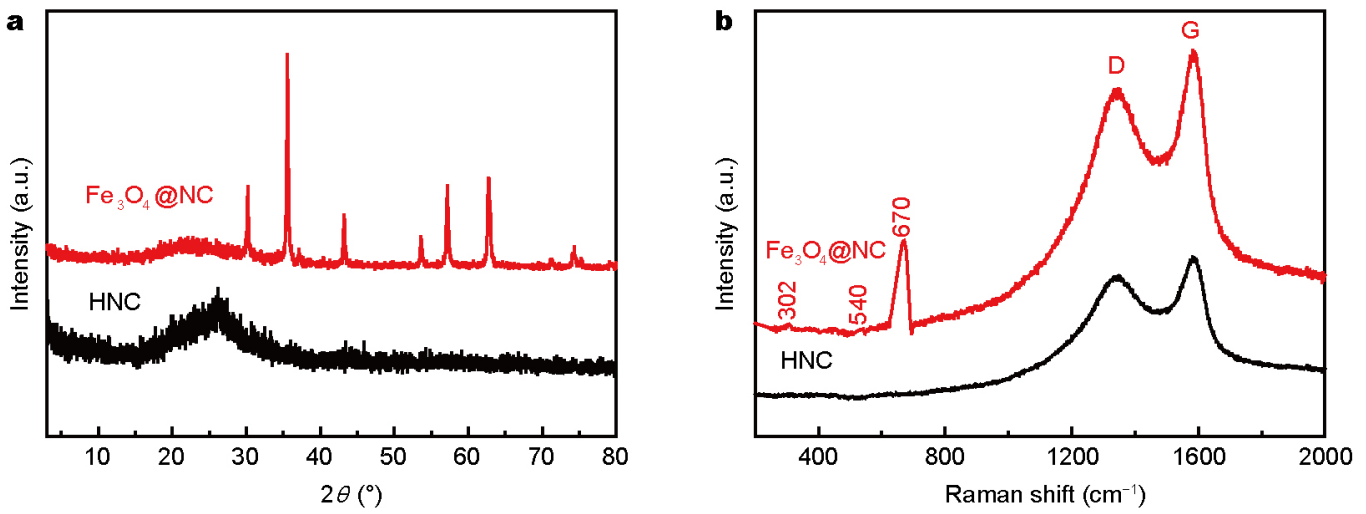

Figure 4 The XRD patterns (a) and Raman spectra (b) of the corresponding electrodes.

The carbon-layer coating on the $\mathrm{Fe}_{3} \mathrm{O}_{4}$ nanoparticles forms a new order of structural hierarchy, as evidenced by the conductive network formed throughout the composites, preventing agglomeration of the $\mathrm{Fe}_{3} \mathrm{O}_{4}$ nanoparticles and accommodating the volume expansion/shrinkage in the process of charging and discharging, which are regarded as key issues for alleviating the poor cycling performance of conventional $\mathrm{Fe}_{3} \mathrm{O}_{4}$-based devices [32,33]. Further evidence of the porous structure was derived from analysis of the nitrogen sorption isotherms of the $\mathrm{Fe}_{3} \mathrm{O}_{4} @ \mathrm{NC}$ composite (Fig. S2). The specific surface area of $\mathrm{Fe}_{3} \mathrm{O}_{4} @ \mathrm{NC}$ is $144.9 \mathrm{~m}^{2} \mathrm{~g}^{-1}$, which is favorable for ef- fective electrolyte permeation. Therefore, the small $\mathrm{Fe}_{3} \mathrm{O}_{4}$ particles coated by thin carbon capsules, in conjunction with the enhanced conductivity and electrolyte accessibility, should lead to improved electrochemical properties.

The XPS analyses of the $\mathrm{Fe}_{3} \mathrm{O}_{4} @ \mathrm{NC}$ composites are summarized in Fig. S3. The Fe 2p spectra (Fig. S3a) present two obvious peaks centered at binding energies (BE) of 710.2 and $723.9 \mathrm{eV}$. The deconvoluted $\mathrm{Fe} 2 \mathrm{p}_{3 / 2}$ peaks at 709.7 , 710.8 , and $713.2 \mathrm{eV}$ are attributed to the $\mathrm{Fe}^{2+}$ octahedral site, $\mathrm{Fe}^{3+}$ octahedral site, and $\mathrm{Fe}^{3+}$ tetrahedral site in $\mathrm{Fe}_{3} \mathrm{O}_{4}$, in agreement with the literature [34-36]. O 1s XPS analysis was carried out to verify the surface oxygen states of 
the $\mathrm{Fe}_{3} \mathrm{O}_{4} @ \mathrm{NC}$ composites (Fig. S3b). The O 1s peak of the $\mathrm{Fe}_{3} \mathrm{O}_{4} @ \mathrm{NC}$ composites at $530 \mathrm{eV}$ could be deconvoluted to two components at 529.5 and $531.6 \mathrm{eV}$, which correspond to the lattice $\mathrm{O}^{2-}$ of metallic oxides or the physically sorbed $\mathrm{H}_{2} \mathrm{O}$ [37-38]. The C 1s XPS spectra (Fig. S3c) could be deconvoluted into three peaks: $\mathrm{sp}^{2}-\mathrm{sp}^{2} \mathrm{C}(284.0 \mathrm{eV}),-\mathrm{C}-\mathrm{N}$ $(284.9 \mathrm{eV})$, and $\mathrm{C}=\mathrm{O}(288.0 \mathrm{eV})[12,15]$. The $\mathrm{N}$ 1s core level (Fig. S3d) could be deconvoluted into two distinct peaks: pyridinic $\mathrm{N}(398.0 \mathrm{eV})$ and pyrrolic $\mathrm{N}(399.5 \mathrm{eV})$ [22,23].

The nitrogen sorption isotherms of the HNC (Fig. S4a) are type-I/IV, and the BET surface area is $804.8 \mathrm{~m}^{2} \mathrm{~g}^{-1}$. The high contact area between the $\mathrm{Fe}_{3} \mathrm{O}_{4}$ nanoparticles and the interconnected carbon capsules is favorable for accelerating charge transfer and furnishing excellent rate capability. The pore size distribution of the HNC (Fig. S4b) was measured to be $9.7 \mathrm{~nm}$.

The XPS spectra in Fig. S5 were used to elucidate the electronic structure of the core levels, with peaks of $\mathrm{sp}^{2} \mathrm{C}$ at $284.5 \mathrm{eV},-\mathrm{C}-\mathrm{N}$ at $285.2 \mathrm{eV}$, and $\mathrm{C}=\mathrm{O}$ at $288.0 \mathrm{eV}$ in the $\mathrm{C}$ 1 s region, along with pyridinic $\mathrm{N}(398.5 \mathrm{eV})$ and pyrrolic $\mathrm{N}$ $(400.2 \mathrm{eV})$ in the $\mathrm{N} 1 \mathrm{~s}$ region, demonstrating the successful combination of these elements $[15,22]$.

\section{Li-ion battery performance}

The lithium storage performance of the $\mathrm{Fe}_{3} \mathrm{O}_{4} @ \mathrm{NC}$ composite as an anode material was assessed by using coin-type cells. Fig. 5a shows the first three cycles in the CV curves of the $\mathrm{Fe}_{3} \mathrm{O}_{4} @ \mathrm{NC}$ electrode. Two distinct peaks are located
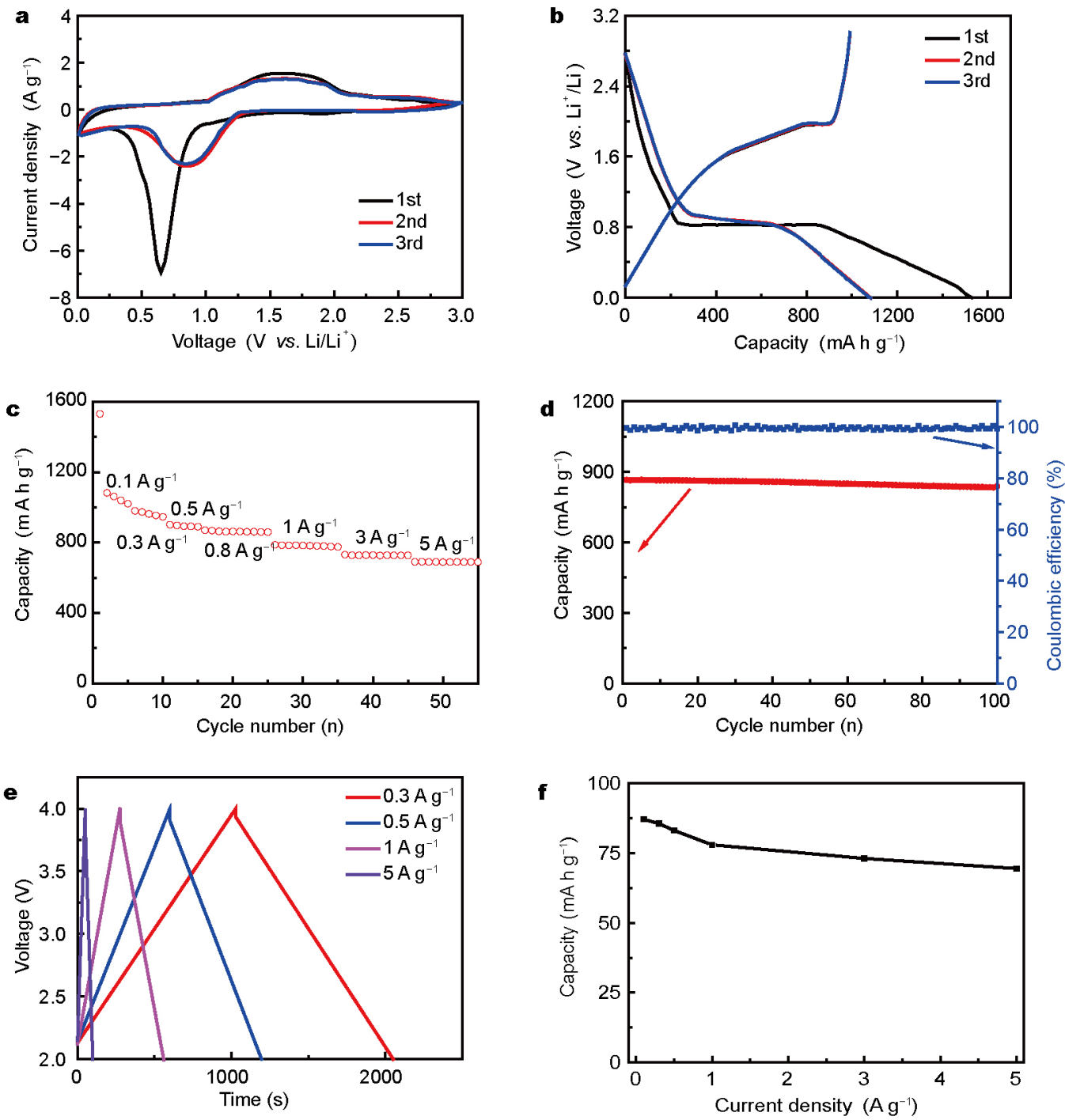

Figure 5 (a) CV curves at $0.5 \mathrm{mV} \mathrm{s}^{-1}$, (b) charge-discharge curves, (c) rate performance, (d) cycle stability of the $\mathrm{Fe}_{3} \mathrm{O}_{4} @ \mathrm{NC}$ electrode. (e) Galvanostatic charge-discharge curves, (f) discharge capacities of HNC-based Li-ion battery at different current densities. 
at 0.64 and $0.49 \mathrm{~V}\left(v s . \mathrm{Li}^{+} / \mathrm{Li}\right)$ in the first cycle of the cathodic scan, which may correspond to the reaction: $\mathrm{Fe}_{3} \mathrm{O}_{4}$ $+8 \mathrm{Li}^{+} \rightarrow 3 \mathrm{Fe}^{0}+4 \mathrm{Li}_{2} \mathrm{O}$ [39]. The oxidation peak around 1.87 $\mathrm{V}$ in the anodic scan can be ascribed to the oxidation of $\mathrm{Fe}^{0}$ to $\mathrm{Fe}_{3} \mathrm{O}_{4}[13,20]$. In the successive scans, the anodic and cathodic peaks are both shifted and the peak intensity drops significantly, corresponding to polarization of the electrode [40]. In addition, the CV curves of the post two cycles approximately overlap, implying good invertibility.

As shown in Fig. 5b, the cell exhibits a specific capacity of $1530 \mathrm{~mA} \mathrm{~h} \mathrm{~g}^{-1}$ during the first discharge procedure. During the corresponding charge process, the obtained reversible capacity is $992 \mathrm{~mA} \mathrm{~h} \mathrm{~g}^{-1}$, corresponding to an initial Coulombic efficiency of about $65 \%$. The formation of a solid electrolyte interface (SEI) film causes irreversible capacity loss in the first cycle $[41,42]$. In the subsequent cycles, there are no obvious changes in the charge-discharge profiles, demonstrating outstanding capacity retention. In addition, the specific capacity of the $\mathrm{Fe}_{3} \mathrm{O}_{4} @ \mathrm{NC}$ electrode decreases slowly with increasing discharge current density, demonstrating excellent rate performance (Fig. 5c). When the current density increases to $5 \mathrm{~A} \mathrm{~g}^{-1}$, the specific capacity of the $\mathrm{Fe}_{3} \mathrm{O}_{4} @ \mathrm{NC}$ electrode still remains at $690 \mathrm{~mA} \mathrm{~h}$ $\mathrm{g}^{-1}$, which corresponds to retention of $45 \%$ of the initial capacity. In addition, the $\mathrm{Fe}_{3} \mathrm{O}_{4} @ \mathrm{NC}$ electrode exhibits good cycle stability, as depicted in Fig. 5d. At $0.8 \mathrm{~A} \mathrm{~g}^{-1}$ current density, after 100 cycles, a specific capacity retention of $>97 \%$ was achieved, with nearly perfect Coulombic efficiency in each cycle. TEM observation (Fig. S6) reveals that the structural integrity is well maintained even after 100 charge-discharge cycles, indicative of the stable operation of the $\mathrm{Fe}_{3} \mathrm{O}_{4} @ \mathrm{NC}$ hybrids.

The above results clearly demonstrate that the mesoporous core-shell structure of the $\mathrm{Fe}_{3} \mathrm{O}_{4} @ \mathrm{NC}$ composite plays a crucial role in enhancing the electrochemical properties. The promising performance is due to the following four critical aspects. Firstly, the uniform building subunits are beneficial for fast transport of lithium ions and electrons and provide a high surface area, leading to the excellent rate capability. Secondly, the carbon shells can prevent direct contact between $\mathrm{Fe}_{3} \mathrm{O}_{4}$ and the electrolyte, consequently lessening the interfacial reactions, which is crucial for structural stabilization of the electrode. Thirdly, the mesoporous structure can tolerate the volume expansion/contraction during the charge-discharge process, resulting in remarkable structural stability. Finally, the carbon capsules are strongly interconnected with the sub-units to form a continuous network, leading to good electrical conductivity and enhanced electrochemical per- formance. Such extraordinary properties of the $\mathrm{Fe}_{3} \mathrm{O}_{4} @ \mathrm{NC}$ make it a good candidate for Li-HECs and provide enhanced electrochemical performance.

The linear galvanostatic charge-discharge curve of the HNC electrode (Fig. 5e) indicates capacitive behavior, corresponding to the adsorption-desorption of ions on the electrode surface. The HNC has a high discharge capacity of $87 \mathrm{~mA} \mathrm{~h} \mathrm{~g}^{-1}$ at $0.1 \mathrm{~A} \mathrm{~g}^{-1}$ current density. With increasing discharge current density, the discharge capacity of the HNC electrode decreases slowly, demonstrating excellent rate capacity (Fig. 5f). Even when the current density was increased to $5 \mathrm{~A} \mathrm{~g}^{-1}$, the specific capacity of the HNC electrode still remained at $69.4 \mathrm{~mA} \mathrm{~h} \mathrm{~g}^{-1}$ (79\% of the initial capacity). Thus, it can be concluded that the $3 \mathrm{D}$ micro-structure effectively improves the diffusion kinetics and enhances the lithium storage ability.

\section{Li-HEC performance}

Asymmetrically assembled Li-HECs can achieve high-voltage, giving rise to high energy and power density of the devices. Therefore, Li-HECs were assembled using $\mathrm{Fe}_{3} \mathrm{O}_{4} @ \mathrm{NC}$ as the anode and $\mathrm{HNC}$ as the cathode. In the charging process, the porous capsules of the HNC can adsorb $\mathrm{PF}_{6}^{-}$ions from the electrolyte, while $\mathrm{Li}^{+}$ions are intercalated into the $\mathrm{Fe}_{3} \mathrm{O}_{4} @ \mathrm{NC}$ electrode. The electrode discharge process involves the reverse sequence of events. To achieve high energy density of the Li-HECs, the mass ratio of the electrodes and the voltage window must be optimized to achieve the best state of both the anode and cathode. As illustrated in Fig. 5b, the plateau region of the $\mathrm{Fe}_{3} \mathrm{O}_{4} @ \mathrm{NC}$ anode is located at about $0.9 \mathrm{~V}\left(v s . \mathrm{Li} / \mathrm{Li}^{+}\right)$. Thus, the plot for the HNC cathode has a linear region from 2.5 to $4.0 \mathrm{~V}$ ( $v$. $\mathrm{Li} / \mathrm{Li}^{+}$) (Fig. 5e), indicating that the maximum charge voltage can reach $4.0 \mathrm{~V}$ (vs. $\mathrm{Li} / \mathrm{Li}^{+}$). Hence, the performance of the Li-HEC device was evaluated in the range of 1.0 to $4.0 \mathrm{~V}\left(v s . \mathrm{Li} / \mathrm{Li}^{+}\right)$. Based on the equation: $Q_{+}=Q_{-}$, the mass ratio of the electrode active materials is optimized to $4: 1$.

The CV curves of the Li-HECs adopt a quasi-rectangular shape irrespective of the scan rate due to the superimposed effects of the two different energy-storage mechanisms (Fig. 6a). The representative charge-discharge profiles (Fig. 6b) illustrate a similar linear relationship, which is in accordance with the ideal capacitor performance. Furthermore, at a current density of $0.5 \mathrm{~A} \mathrm{~g}^{-1}$, the $\mathrm{Fe}_{3} \mathrm{O}_{4} @ \mathrm{NC} / / \mathrm{HNC}$ Li-HEC exhibits an ultrahigh capacitance of $245 \mathrm{~F} \mathrm{~g}^{-1}$ (Fig. S7). Even when the current density reaches $40 \mathrm{~A} \mathrm{~g}^{-1}$ (rapid charging/discharging within $9 \mathrm{~s}$, Fig. S8), the capacitance retention is maintained at $65.3 \%$, indicating the excellent 

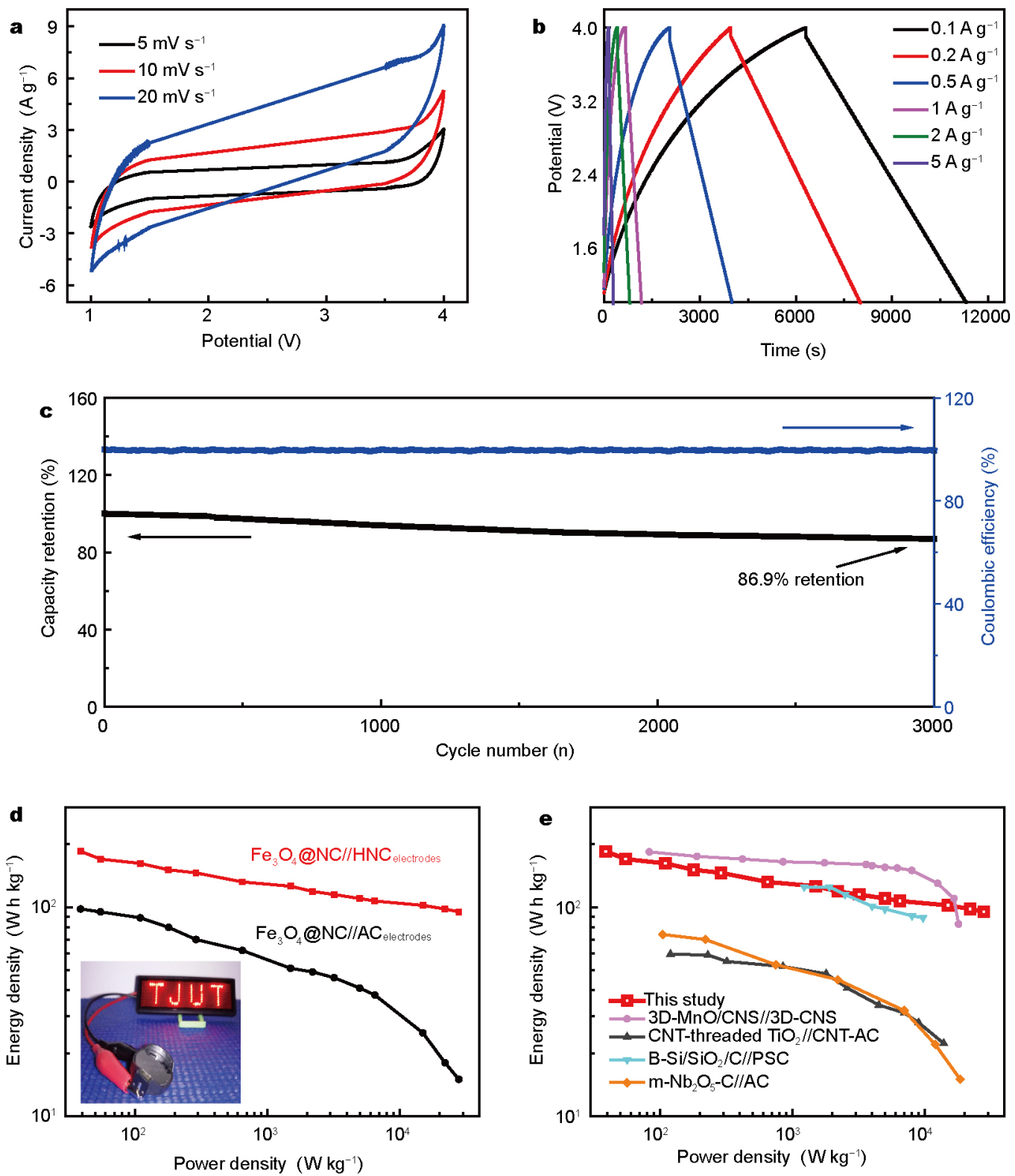

Figure 6 Electrochemical performance of the $\mathrm{Fe}_{3} \mathrm{O}_{4} @ \mathrm{NC} / / \mathrm{HNC}$ Li-HECs. (a) CV curves, b) galvanostatic charge-discharge curves, c) cycle stability of the $\mathrm{Fe}_{3} \mathrm{O}_{4} @ \mathrm{NC} / / \mathrm{HNC}$ Li-HECs over 3000 cycles at a current density of $5 \mathrm{~A} \mathrm{~g}^{-1}$. (d) Ragone plots of the $\mathrm{Fe}_{3} \mathrm{O}_{4} @ \mathrm{NC} / / \mathrm{HNC} \mathrm{Li}-\mathrm{HECs}$ and Fe $\mathrm{O}_{4} @ \mathrm{NC} / / \mathrm{AC}$ Li-HECs at various charge-discharge rates. (e) Ragone plots (energy density vs. power density) of the $\mathrm{Fe}_{3} \mathrm{O}_{4} @ \mathrm{NC} / / \mathrm{HNC}$ Li-HECs compared with other reported hybrid supercapacitors (all based on total mass of both electrodes).

rate capability. The $\mathrm{Fe}_{3} \mathrm{O}_{4} @ \mathrm{NC} / / \mathrm{AC}$ device was also constructed for comparison. The $\mathrm{Fe}_{3} \mathrm{O}_{4} @ \mathrm{NC} / / \mathrm{HNC}$ system exhibits a certain extent of enhancement relative to the $\mathrm{Fe}_{3} \mathrm{O}_{4} @ \mathrm{NC} / / \mathrm{AC}$ configuration, confirming the complementarity of the as-synthesized anode and cathode materials in the former (Fig. S9). At a high current density of $5 \mathrm{~A} \mathrm{~g} \mathrm{~g}^{-1}$, the Li-HECs also presents favorable cyclic stability (Fig. 6c) with a capacity retention of $91.2 \%$ after 1500 cycles that could be maintained up to 3000 cycles (with
$86.9 \%$ retention), as well as good Coulombic efficiency.

The interfacial electron and ion transfer process was evaluated by EIS (Fig. S10). The EIS data could be fitted to an equivalent circuit consisting of the bulk solution resistance $R_{\mathrm{s}}$, charge-transfer resistance $R_{\mathrm{ct}}$, pseudocapacitive element $C_{\mathrm{p}}$ of the redox process, and the constant phase element (CPE) to account for the double-layer capacitance. $R_{\mathrm{s}}$ and $R_{\mathrm{ct}}$ can be obtained from the Nyquist plots, where the high-frequency semicircle intercepts the real axis at $R_{\mathrm{s}}$ 
and $\left(R_{\mathrm{s}}+R_{\mathrm{ct}}\right)$, respectively. The charge-transfer resistance is deduced by fitting the EIS data. From the results shown in Fig. S10, the deduced solution resistance, $R_{\mathrm{s}}$, is $28 \Omega$, and the charge-transfer resistance, $R_{\mathrm{ct}}$, is $82 \Omega$ for the $\mathrm{Fe}_{3} \mathrm{O}_{4} @ \mathrm{NC} / / \mathrm{HNC}$ Li-HEC device. The more vertical line leaning towards the imaginary axis in the low-frequency region of the $\mathrm{Fe}_{3} \mathrm{O}_{4} @ \mathrm{NC} / / \mathrm{HNC}$ Li-HECs device indicates the lower $\mathrm{CPE}$ value. This suggests more facile electrolyte diffusion to the composite surface and more ideal capacitor behavior. The above results demonstrate that the combination of fast ion diffusion and low charge-transfer resistance results in high utilization of the active materials, thereby enhancing the electrochemical properties of the $\mathrm{Fe}_{3} \mathrm{O}_{4} @ \mathrm{NC} / / \mathrm{HNC}$ Li-HECs device.

The Ragone plots of the $\mathrm{Fe}_{3} \mathrm{O}_{4} @ \mathrm{NC} / / \mathrm{HNC}$ and $\mathrm{Fe}_{3} \mathrm{O}_{4} @ \mathrm{NC} / / \mathrm{AC}$ Li-HECs are shown in Fig. 6d. The energy and power density were determined based on the total mass of both electrodes. The energy density and power density of the $\mathrm{Fe}_{3} \mathrm{O}_{4} @ \mathrm{NC} / / \mathrm{HNC}$ system are much higher than that of the $\mathrm{Fe}_{3} \mathrm{O}_{4} @ \mathrm{NC} / / \mathrm{AC}$ system. For instance, the $\mathrm{Fe}_{3} \mathrm{O}_{4} @ \mathrm{NC} / / \mathrm{HNC}$ Li-HEC system delivers a high-level energy density of $151 \mathrm{~W} \mathrm{~h} \mathrm{~kg}^{-1}$ electrodes at $180 \mathrm{~W} \mathrm{~kg}^{-1}$ and $185 \mathrm{~W} \mathrm{~h} \mathrm{~kg}^{-1}$ electrodes at $39 \mathrm{~W} \mathrm{~kg}^{-1}$, while the $\mathrm{Fe}_{3} \mathrm{O}_{4} @ \mathrm{NC} / / \mathrm{AC}$ device affords only $80 \mathrm{~W} \mathrm{~h} \mathrm{~kg}^{-1}$ electrodes at $180 \mathrm{~W} \mathrm{~kg}^{-1}$. Even when the power density reaches $28 \mathrm{~kW} \mathrm{~kg}^{-1}$, which is well above the suggested target $\left(15 \mathrm{~kW} \mathrm{~kg}^{-1}\right)$ for electric vehicles, the $\mathrm{Fe}_{3} \mathrm{O}_{4} @ \mathrm{NC} / / \mathrm{HNC}$ device maintains an energy density of $95 \mathrm{~W} \mathrm{~h} \mathrm{~kg}^{-1}$ electrodes, demonstrating its exceptional rate performance. From comparison of the performance of the Li-HECs with the best Li-ion capacitor systems reported to date (Table $\mathrm{S} 1$ ), such as $\mathrm{B}-\mathrm{Si}_{2} / \mathrm{SiO}_{2} / \mathrm{C} / / \mathrm{PSC}$ [14], 3D-MnO/CNS//3D-CNS [21], $\quad \mathrm{m}-\mathrm{Nb}_{2} \mathrm{O}_{5}-\mathrm{C} / / \mathrm{AC}$ [33], CNT-threaded $\mathrm{TiO}_{2} / / \mathrm{CNT}-\mathrm{AC}$ [41], etc., it can be concluded that the developed Li-HEC exhibits one of the most promising energy-power combinations (Fig. 6e). Since the mass of both electrodes accounts for $30 \%-40 \%$ of the entire system, the overall Li-HEC system presents hope for achieving hundred-W $\mathrm{h} \mathrm{kg}^{-1}$ energy density as well as retaining capacitor-level power density (Fig. S11), and represents a superb energy-power combination for bridging the gap between LIBs and capacitors. An energy density of $54 \mathrm{~W} \mathrm{~h} \mathrm{~kg}^{-1}$ package could be achieved at a power density of $4000 \mathrm{~W} \mathrm{~kg}^{-1}$ package. Likewise, an energy density of $49 \mathrm{~W} \mathrm{~h} \mathrm{~kg}^{-1}$ package could be maintained even at the ultrahigh package power of $9000 \mathrm{~W} \mathrm{~kg}^{-1}$ package. As shown in Fig. $6 \mathrm{~d}$ (inset) and Fig. S12, a single $3 \mathrm{~V}$ Li-HEC can readily drive light-emitting diodes (LEDs) where the signal "TJUT" could be observed, which implies the potential for practical application of the Li-HECs.

\section{CONCLUSIONS}

In summary, an anode and cathode $\left(\mathrm{Fe}_{3} \mathrm{O}_{4} @ \mathrm{NC} / / \mathrm{HNC}\right)$ couple was fabricated by a facile process and subsequently applied in Li-HECs. The core-shell structure of the $\mathrm{Fe}_{3} \mathrm{O}_{4} @ \mathrm{NC}$ anode provides a large specific surface area and restricts diffusion-controlled lithiation/delithiation processes, while the HNC cathode with tailored micro/meso-porosity exhibits enhanced super-capacitive performance. Based on the design of the electrode materials, energy densities of $185-95 \mathrm{~W} \mathrm{~h} \mathrm{~kg}^{-1}$ were achieved with the Li-HECs, along with power densities ranging from 39 to $28,000 \mathrm{~W} \mathrm{~kg}$, which are almost the highest values reported for hybrid-type systems. These Li-HECs, which combine high energy and power performance, narrow the gap between supercapacitors and batteries, and represent a forward step in this field.

Received 7 December 2016; accepted 2 February 2017; published online 20 February 2017

1 Armand M, Tarascon JM. Building better batteries. Nature, 2008, 451: $652-657$

2 Wang G, Zhang L, Zhang J. A review of electrode materials for electrochemical supercapacitors. Chem Soc Rev, 2012, 41: 797-828

3 Amatucci GG, Badway F, Du Pasquier A, et al. An asymmetric hybrid nonaqueous energy storage cell. J Electrochem Soc, 2001, 148: A930-939

4 Plitz I, Dupasquier A, Badway F, et al. The design of alternative nonaqueous high power chemistries. Appl Phys A, 2006, 82: 615-626

5 Naoi K, Naoi W, Aoyagi S, et al. New generation "nanohybrid supercapacitor”. Acc Chem Res, 2013, 46: 1075-1083

6 Wang Y, Xia Y. Recent progress in supercapacitors: from materials design to system construction. Adv Mater, 2013, 25: 5336-5342

7 Aravindan V, Gnanaraj J, Lee YS, et al. Insertion-type electrodes for nonaqueous Li-ion capacitors. Chem Rev, 2014, 114: 11619-11635

8 Dubal DP, Ayyad O, Ruiz V, et al. Hybrid energy storage: the merging of battery and supercapacitor chemistries. Chem Soc Rev, 2015, 44: $1777-1790$

9 Ma Y, Chang H, Zhang M, et al. Graphene-based materials for lithium-ion hybrid supercapacitors. Adv Mater, 2015, 27 : 5296-5308

10 Choi HS, Im JH, Kim TH, et al. Advanced energy storage device: a hybrid BatCap system consisting of battery-supercapacitor hybrid electrodes based on $\mathrm{Li}_{4} \mathrm{Ti}_{5} \mathrm{O}_{12}$-activated-carbon hybrid nanotubes. J Mater Chem, 2012, 22: 16986-16993

11 Iwama E, Kawabata N, Nishio N, et al. Enhanced electrochemical performance of ultracentrifugation-derived $\mathrm{nc}-\mathrm{Li}_{3} \mathrm{VO}_{4} / \mathrm{MWCNT}$ composites for hybrid supercapacitors. ACS Nano, 2016, 10: 5398-5404

12 Yang $\mathrm{M}$, Zhong $\mathrm{Y}$, Ren J, et al. Fabrication of high-power Li-ion hybrid supercapacitors by enhancing the exterior surface charge storage. Adv Energ Mater, 2015, 5: 1500550

13 Zhang F, Zhang T, Yang X, et al. A high-performance supercapacitor-battery hybrid energy storage device based on graphene-enhanced electrode materials with ultrahigh energy density. Energ Environ Sci, 2013, 6: 1623-1632 
14 Yi R, Chen S, Song J, et al. High-performance hybrid supercapacitor enabled by a high-rate Si-based anode. Adv Funct Mater, 2014, 24: 7433-7439

15 Li B, Dai F, Xiao Q, et al. Nitrogen-doped activated carbon for a high energy hybrid supercapacitor. Energ Environ Sci, 2016, 9: 102-106

16 Li B, Dai F, Xiao Q, et al. Activated carbon from biomass transfer for high-energy density lithium-ion supercapacitors. Adv Energ Mater, 2016, 6: 1600802

17 Yang S, Feng X, Ivanovici S, et al. Fabrication of graphene-encapsulated oxide nanoparticles: towards high-performance anode materials for lithium storage. Angew Chem Int Ed, 2010, 49: 8408-8411

18 Piao Y, Kim HS, Sung YE, et al. Facile scalable synthesis of magnetitenanocrystals embedded in carbon matrix as superior anode materials for lithium-ion batteries. Chem Commun, 2010, 46: $118-120$

19 Jiang $\mathrm{H}$, Hu Y, Guo S, et al. Rational design of $\mathrm{MnO} /$ carbon nanopeapods with internal void space for high-rate and long-life Li-ion batteries. ACS Nano, 2014, 8: 6038-6046

20 Li H, Xu R, Wang Y, et al. In situ synthesis of hierarchical mesoporous $\mathrm{Fe}_{3} \mathrm{O}_{4} @ \mathrm{C}$ nanowires derived from coordination polymers for high-performance lithium-ion batteries. RSC Adv, 2014, 4: 51960-51965

21 Wang H, Xu Z, Li Z, et al. Hybrid device employing three-dimensional arrays of $\mathrm{MnO}$ in carbon nanosheets bridges battery-supercapacitor divide. Nano Lett, 2014, 14: 1987-1994

22 Mhamane D, Aravindan V, Kim MS, et al. Silica-assisted bottom-up synthesis of graphene-like high surface area carbon for highly efficient ultracapacitor and Li-ion hybrid capacitor applications. J Mater Chem A, 2016, 4: 5578-5591

23 Sennu P, Aravindan V, Ganesan M, et al. Biomass-derived electrode for next generation lithium-ion capacitors. ChemSusChem, 2016, 9: 849-854

24 Zhang LL, Zhao XS. Carbon-based materials as supercapacitor electrodes. Chem Soc Rev, 2009, 38: 2520-2531

25 Pandolfo AG, Hollenkamp AF. Carbon properties and their role in supercapacitors. J Power Sources, 2006, 157: 11-27

26 Li W, Zhang F, Dou Y, et al. A self-template strategy for the synthesis of mesoporous carbon nanofibers as advanced supercapacitor electrodes. Adv Energ Mater, 2011, 1: 382-386

27 Guo X, Liu P, Han J, et al. 3D nanoporous nitrogen-doped graphene with encapsulated $\mathrm{RuO}_{2}$ nanoparticles for $\mathrm{Li}-\mathrm{O}_{2}$ batteries. Adv Mater, 2015, 27: 6137-6143

28 Qin K, Liu E, Li J, et al. Free-standing 3D nanoporous duct-like and hierarchical nanoporous graphene films for micron-level flexible solid-state asymmetric supercapacitors. Adv Energ Mater, 2016, 6: 1600755

29 Han J, Guo X, Ito Y, et al. Effect of chemical doping on cathodic performance of bicontinuous nanoporous graphene for $\mathrm{Li}^{-\mathrm{O}_{2}}$ batteries. Adv Energ Mater, 2016, 6: 1501870

30 Zhou G, Wang DW, Li F, et al. Graphene-wrapped $\mathrm{Fe}_{3} \mathrm{O}_{4}$ anode material with improved reversible capacity and cyclic stability for lithium ion batteries. Chem Mater, 2010, 22: 5306-5313

31 Ferrari AC, Basko DM. Raman spectroscopy as a versatile tool for studying the properties of graphene. Nat Nanotech, 2013, 8 : 235-246

32 Simon P, Gogotsi Y, Dunn B. Where do batteries end and supercapacitors begin? Science, 2014, 343: 1210-1211

33 Lim E, Kim H, Jo C, et al. Advanced hybrid supercapacitor based on a mesoporous niobium pentoxide/carbon as high-performance anode. ACS Nano, 2014, 8: 8968-8978

34 McIntyre NS, Zetaruk DG. X-ray photoelectron spectroscopic studies of iron oxides. Anal Chem, 1977, 49: 1521-1529

35 Poulin S, França R, Moreau-Bélanger L, et al. Confirmation of $\mathrm{X}$-ray photoelectron spectroscopy peak attributions of nanoparticulate iron oxides, using symmetric peak component line shapes. J Phys Chem C, 2010, 114: 10711-10718

36 Wilson D, Langell MA. XPS analysis of oleylamine/oleic acid capped $\mathrm{Fe}_{3} \mathrm{O}_{4}$ nanoparticles as a function of temperature. Appl Surface Sci, 2014, 303: 6-13

37 Biesinger MC, Payne BP, Grosvenor AP, et al. Resolving surface chemical states in XPS analysis of first row transition metals, oxides and hydroxides: Cr, Mn, Fe, Co and Ni. Appl Surface Sci, 2011, 257: 2717-2730

38 Eltouny NA, Ariya PA. $\mathrm{Fe}_{3} \mathrm{O}_{4}$ nanoparticles and carboxymethyl cellulose: a green option for the removal of atmospheric benzene, toluene, ethylbenzene, and $o$-xylene (BTEX). Ind Eng Chem Res, 2012, 51: 12787-12795

39 He Y, Huang L, Cai JS, et al. Structure and electrochemical performance of nanostructured $\mathrm{Fe}_{3} \mathrm{O}_{4} /$ carbon nanotube composites as anodes for lithium ion batteries. Electrochim Acta, 2010, 55: $1140-1144$

40 Wang JZ, Zhong C, Wexler D, et al. Graphene-encapsulated $\mathrm{Fe}_{3} \mathrm{O}_{4}$ nanoparticles with 3D laminated structure as superior anode in lithium ion batteries. Chem Eur J, 2011, 17: 661-667

41 Chen Z, Yuan Y, Zhou H, et al. 3D nanocomposite architectures from carbon-nanotube-threaded nanocrystals for high-performance electrochemical energy storage. Adv Mater, 2014, 26: 339-345

42 Yan J, Fan Z, Sun W, et al. Advanced asymmetric supercapacitors based on $\mathrm{Ni}(\mathrm{OH})_{2} /$ graphene and porous graphene electrodes with high energy density. Adv Funct Mater, 2012, 22: 2632-2641

Acknowledgments This work was supported by the National Natural Science Foundation of China (51601127, 21603162 and 51671145), China Post-doctoral Science Fund (2015M581304), Tianjin Municipal Education Commission, Tianjin Municipal Science and Technology Commission (16ZXCLGX00120) and the Fundamental Research Funds of Tianjin University of Technology.

Author contributions An $\mathrm{C}$ and Gao $\mathrm{Z}$ designed and performed the experiments; An C wrote the manuscript with support from Liu X. Ding Y supervised the project and revised the manuscript. All authors contributed to the general discussion.

Conflict of interest The authors declare that they have no conflict of interest.

Supplementary information Supporting data are available in the online version of the paper. 

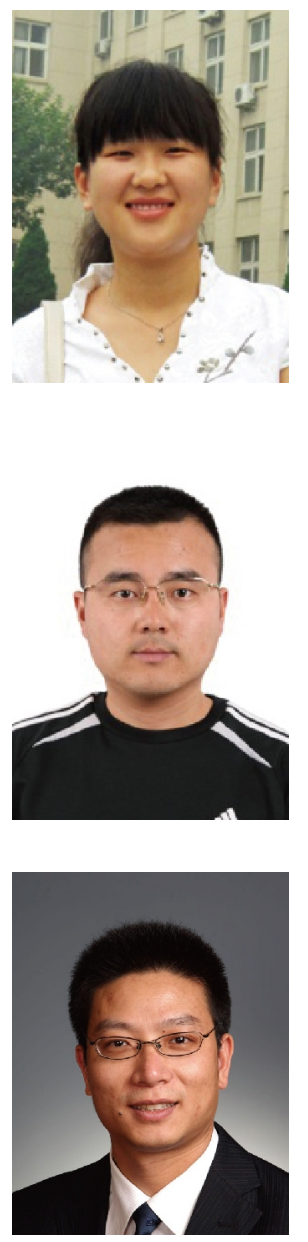

Cuihua An is currently a research scientist at Tianjin University of Technology (TUT). She received her PhD degree from Nankai University in 2015, and then joined the Institute for New Energy Materials \& Low-Carbon Technologies at TUT as a postdoctor. Her research focuses on the design and synthesis of nano/micromaterials and their applications in Li ion batteries and supercapacitors.
Xizheng Liu is currently an associate professor at TUT. He received his PhD degree from the University of Tsukuba in 2014, and then worked as a postdoctor in AIST, Japan, from 2014 to 2015. He joined the Institute for New Energy Materials \& Low-Carbon Technologies at TUT in Aug. 2015. His research interests include the development of novel electrode materials for $\mathrm{Li} / \mathrm{Na}$ ion batteries, supercapacitor, metal-air battery and the related electrochemical reaction mechanisms.

Yi Ding is currently a distinguished professor at the Institute for New Energy Materials \& Low-Carbon Technologies, TUT. He received his PhD degree from Johns Hopkins University in 2005, and then took a faculty position at Shandong University as a Tai-Shan Scholar. In Jan. 2015, he moved to TUT to establish Tianjin Key Laboratory of Advanced Functional Porous Materials. His research interests focus on creating functional nanoporous metal materials for the use in advanced energy technologies. He has been granted 30 patents and published 100 journal articles, with a total citation over 7000 times and an $\mathrm{H}$-index of 45 .

\section{面向百瓦时/千克级能量密度锂离子混合超级电容器电极材料的研究}

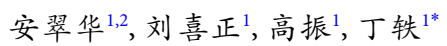

摘要 锂离子混合电容器是一种集合了超级电容器和锂离子电池双重优点的储能器件. 然而, 正负极电极材料的选择和设计仍存在着巨 大的挑战. 本文采用水热反应与热处理相结合的方法, 合成了四氧化三铁纳米颗粒填充的氮掺杂碳胶囊负极材料 $\left(\mathrm{Fe}_{3} \mathrm{O}_{4} @ \mathrm{NC}\right)$, 用稀酸洗去 $\mathrm{Fe}_{3} \mathrm{O}_{4}$ 核, 得到中空的氮掺杂碳胶囊正极材料( $\mathrm{HNC}$ ), 并测定了其作为锂离子混合电容器电极材料的性能. 结果表明, $\mathrm{Fe}_{3} \mathrm{O}_{4} @ \mathrm{NC}$ 负极材料在 $100 \mathrm{~mA} \mathrm{~g}^{-1}$ 电流密度下具有 $1530 \mathrm{~mA} \mathrm{~h} \mathrm{~g}^{-1}$ 的容量, 且具有优异的倍率性能和循环稳定性. 同时 HNC正极材料确保锂离子混合电容器具有大 倍率性能. 结合上述正负极材料的优点, $\mathrm{Fe}_{3} \mathrm{O}_{4} @ \mathrm{NC} / / \mathrm{HNC}$ 锂离子混合电容器在 $39 \mathrm{~W} \mathrm{~kg}$ 的功率密度下表现出 $185 \mathrm{~W} \mathrm{~h} \mathrm{~kg}$ 的能量密度, 并且 当该锂离子混合电容器的能量密度为 $95 \mathrm{~W} \mathrm{~kg}^{-1}$ 时, 其功率密度可高达 $28 \mathrm{~kW} \mathrm{~kg}^{-1}$. 本文采用的制备电极材料的方法操作简便, 廉价易得, 组 装成的锂离子混合电容器具有优异的能量密度和功率密度, 为新型锂离子混合电容器电极材料的设计提供了新思路. 